\title{
A tale of two millennials
}

\author{
Alexa Delbosc \\ Monash University \\ alexa.delbosc@monash.edu
}

\author{
Kelcie Ralph \\ Rutgers University \\ kelcie.r@gmail.com
}

Abstract: In recent years, the millennial generation (those born roughly between 1980 and 2000) has gained significant attention in transport research. Initial research characterized this generation as multimodal, urban and tech-savvy; they have at times been painted as our great hope for a sustainable transport future. Yet more recently a parallel narrative has emerged. According to this view, millennials are simply reacting to difficult economic circumstances that have restricted their ability to pay for a car. This paper explores the evidence for these two conflicting narratives of the millennial generation and possible reasons why the two narratives have come about. It discusses the implications of the two millennial narratives on both social and technological equity and sets out initial thoughts on how these issues may be addressed in future research and policy.

\section{Article history:}

Received: October 30, 2016

Accepted: May 10, 2017

Available online: June 20, 1017

\section{Introduction}

Something appears to be happening among millennials. If you believe the recent flood of research, compared to previous generations millennials are delaying when they get a driving license (Delbosc $\&$ Currie, 2013; Hjorthol, 2016), they are less likely to own a car (Hjorthol, 2016; Kuhnimhof, Buehler, \& Dargay, 2011; Oakil, Manting, \& Nijland, 2016), they are driving less (McDonald, 2015; Kuhnimhof et al., 2011; Klein \& Smart, 2017) and in some countries they are using public transport more (Grimsrud \& El-Geneidy, 2014; Kuhnimhof et al., 2011; Rive, Thomas, Jones, Frith, \& Chang, 2015). There is still a great deal of speculation over whether millennials will continue these sustainable travel habits as they age (Delbosc, 2016; Oakil et al., 2016; Ministry of Infrastructure and the Environment, 2014), but the underlying narrative of the "multimodal millennial" is quite strong. According to this view, millennials love cities, they love being connected, they're ambivalent about cars and they embrace new transport technologies (Sakaria \& Stehfest, 2013). Millennials are our great hope for a sustainable future and their sustainable travel behavior is to be lauded and supported.

Yet there is also a parallel, more pessimistic, narrative. According to this view, millennials are not actually that different from previous generations of young adults. Instead, they are simply reacting to difficult economic circumstances that have shrunk their ability to pay for a car (Klein \& Smart, 2017). In fact, car-less and multimodal millennials are more likely to be low income, from minority groups and

Copyright 2017 Alexa Delbosc \& Kelcie Ralph

http://dx.doi.org/10.5198/jtlu.2017.1006

ISSN: 1938-7849 | Licensed under the Creative Commons Attribution - Noncommercial License 3.0

The Journal of Transport and Land Use is the official journal of the World Society for Transport and Land Use (WSTLUR) and is published and sponsored by the University of Minnesota Center for Transportation Studies. This paper is also published with additional sponsorship from WSTLUR. 
without a high school degree (Ralph, 2016; Brown, Blumenberg, Taylor, Ralph, \& Turley Voulgaris, 2016). In this narrative, sustainable travel behavior is a symptom of disadvantage rather than a symbol of hope.

What do these two narratives looks like, how did we arrive at them, and what are the equity implications for this generation?

\section{The two narratives of millennials}

A close reading of academic research and grey literature uncovers two distinct narratives around millennial travel behavior.

\subsection{Narrative 1: Millennials as sustainable urbanites}

Narrative 1 is the optimistic narrative of millennials as sustainable travelers who drive less, use public transport more, flock to the cities and embrace technology rather than cars. Papers that feed into this narrative focus on attitudes (reduced preference for cars), mode shifts (more transit use, less driving) and inner-city home location. Their conclusions and recommendations emphasize the need to encourage these trends, often with a focus on increasing transit provision and cycling and walking infrastructure and providing housing in inner-city areas.

This is the narrative often taken up in "grey literature" reports (e.g., Davis, Dutzik, \& Baxandall, 2012; Sakaria \& Stehfest, 2013; Zipcar, 2013) and popular media (e.g., Campbell, 2012).

\subsection{Narrative 2: Millennials left behind in the suburbs}

Narrative 2 is a more somber view in which millennials are driving less primarily because of reduced incomes and a delay in "adult" milestones. These papers note reduced travel overall (often finding no evidence of increased transit use), particularly among low-income groups, ethnic minorities or recent migrants. According to these studies, much of the decline in driving took place beyond city centers in transit-poor suburbs and rural areas.

The recommendations from these papers are more restrained about a fundamental shift in preferences and behaviors, suggesting that many millennials will likely drive more if and when their circumstances improve. This narrative is less often explored in "grey literature" reports or popular media.

Moreover, the less-educated and low-income millennials may face a greater need to drive than their more educated peers for a number of reasons. They are more likely to have children and at a younger age; research suggests that it is more difficult to meet modern parenting obligations without a vehicle (Taylor, Ralph, \& Smart, 2015). They are more likely to live in suburban settings than in the past (particularly in the United States) and have dispersed, low-income employment (service-sector jobs, construction and caregiving). Trade-based jobs require people to carry tools of their trade, whereas shift work is not well-serviced by public transport and walking, especially late at night. This may be why there is little evidence that access to transit improves job outcomes for low-income employment (Blumenberg \& Manville, 2004)

\section{$3 \quad$ How did we reach this contradiction?}

In the following section, we explore two possible explanations for the emergence of these two distinct narratives: sampling differences and the storytelling power of Narrative 1. 


\subsection{Sampling differences and millennial narratives}

Both Narratives 1 and 2 exist to varying degrees in cities and countries, but the extent to which they are emphasized depends in part on sampling differences between studies. Table 1 reviews a range of studies on the travel behavior of millennials, classifying them by location, sampling method and which narrative they support. Many of the studies portraying Narrative 1 were conducted in Europe, Australia or Canada, often in cities where transit and active modes are more feasible than in most areas of the United States. Research that focuses on urban areas — especially in the core of urban areas where transit service is extensive — tends to focus on highly educated/urban millennials because that is where those millennials live.

Table 1: Synthesis of studies on the travel of millennials

\begin{tabular}{|l|l|l|l|c|}
\hline \multicolumn{1}{|c|}{ Study } & \multicolumn{1}{|c|}{ Data source } & \multicolumn{1}{c|}{ Country } & Narrative \\
\hline (Sakaria \& Stehfest, 2013) & Own survey (online) & USA & Major metro areas & 1 \\
\hline (Oakil et al., 2016) & Vehicle registration and SSD data & Netherlands & National & 1 \\
\hline (Thigpen \& Handy, 2016) & Own survey (online) & USA & University campus (UC Davis) & 1 \\
\hline (Hjorthol, 2016) & National Travel Survey & Norway & National & 1 \\
\hline (Rive et al., 2015) & Own survey (online) & New Zealand & National & 1 \\
\hline (Grimsrud \& El-Geneidy, 2014) & O-D survey & Canada & City (Montreal) & 1 \\
\hline $\begin{array}{l}\text { (Kuhnimhof, Buehler, Wirtz, \& } \\
\text { Kalinowska, 2012) }\end{array}$ & $\begin{array}{l}\text { German Mobility Panel and } \\
\text { Income and Expenditure Survey }\end{array}$ & Germany & National & 1 \\
\hline (Zipcar, 2013) & Own survey (online) & USA & National & 1 \\
\hline (Delbosc \& Currie, 2014b) & Own survey (intercept) & Australia & City (Melbourne) & 1 \\
\hline (Delbosc, 2016) & Licensing statistics & Australia and USA & National (USA) and State (Victoria) & 1 \\
\hline (Delbosc \& Currie, 2014a) & Household travel survey & Australia & City (Melbourne) & 1 and 2 \\
\hline (McDonald, 2015) & National Household Travel Survey & USA & National & 1 and 2 \\
\hline $\begin{array}{l}\text { (Ministry of Infrastructure and } \\
\text { the Environment, 2014) }\end{array}$ & $\begin{array}{l}\text { National Travel Survey and own } \\
\text { survey (online) }\end{array}$ & Netherlands & National & 1 and 2 \\
\hline (Raimond \& Milthorpe, 2010) & Household Travel Survey & Australia & State (New South Wales) & 1 and 2 \\
\hline (Le Vine \& Polak, 2014) & National Travel Survey & UK & National & 2 \\
\hline (Klein \& Smart, 2017) & Panel Study of Income Dynamics & US & National & National \\
\hline (Brown et al., 2016) & National Household Travel Survey & US & National & 2 \\
\hline (Ralph, 2016) & National Household Travel Survey & US & & 2 \\
\hline
\end{tabular}

Note: Narrative classification is authors' own

Other studies are small and likely over-sample urban, tech-savvy millennials. For example, an oftcited Zipcar survey sampled only 1,000 respondents and has not released its sampling methodology (Zipcar, 2013). Other studies draw on potentially anomalous samples: university campuses (Thigpen \& Handy, 2016), market research web panels (Sakaria \& Stehfest, 2013; Rive et al., 2015), or intercept surveys conducted primarily at train stations (Delbosc \& Currie, 2014b). These studies are likely to under-sample young people who may be struggling to afford automobility or who live in suburban or rural locations.

By contrast, studies that employed a national sample—-beyond just urban areas - tend to emphasize Narrative 2 (Klein \& Smart, 2017, Brown et al.; 2016, Ralph, 2016). National surveys ideally provide a more comprehensive picture of millennial travel patterns than surveys conducted exclusively in urban areas. ${ }^{1}$

\footnotetext{
${ }^{1}$ Importantly, these national studies have their own sampling short-comings. For example, the US National Household Travel survey only sampled households with a landline phone. In 2009 fully a quarter of American households did not have a landline, relying instead on cell phones; by 2015 that figure rose to 43\% (Santos, A., Methipara, J., \& Reuscher, T. 2016).
} 


\subsection{The storytelling power of Narrative 1}

In addition to methodological causes, Narrative 1 may have more prominence due to its power as a compelling story. This could occur in four ways.

First, planners and advocates may focus on Narrative 1 because of a natural tendency to want to see signs of progress. In many places, urban and transportation policymakers have worked for years to build more compact cities and to encourage travel by walking, biking, or transit. Evidence that those efforts were paying off is understandably alluring.

Second, planners and advocates may strategically focus on Narrative 1 if they assume (perhaps correctly) that the best way to support continued efforts to change land use and travel patterns is to focus on success stories. This logic may be particularly compelling if those success stories reflect the experience of highly-educated millennials, who tend to be sought after by development agencies. By contrast, in an era when many governments are cutting back on social services for people in need, advocates may view Narrative 2 as a less compelling case for securing new investments in transit or active modes.

Third, planners and advocates may be drawn to Narrative 1 because many of us embody that narrative and are surrounded by others who embody it too. Not only are planners and advocates typically much more educated than the general population (the majority of whom do not have college degrees), they are also more likely to live in urban areas and to use non-automobile modes (Ralph \& Delbosc, 2017). The fact that many planners and advocates embody Narrative 1 can in turn lead them to overestimate the prevalence of Narrative 1 in the general population (Ralph \& Delbosc, 2017).

Finally, planners and advocates may be exposed to more stories in the media about Narrative 1 for two reasons: many media outlets are based in large cities and urbanization by Narrative 1 was newsworthy because it represented a break from decades of urban decline. Narrative 2, by contrast, may not be as visible to transport professionals unless they work in suburban or rural communities or with lowincome, migrant or less-educated youth.

\section{$4 \quad$ Equity implications of the two millennials}

The coming years and decades will bring changes to transportation systems, which will affect Narratives 1 and 2 differently ${ }^{2}$. Focusing on Narrative 1 and neglecting Narrative 2 will likely have important implications for social equity. We explore three cases below: mobility services, electric vehicles, and road pricing.

\subsection{Mobility services}

A sea change in transportation technology is underway. Some argue that these innovations will facilitate a shift towards mobility-as-a-service (Mulley, 2017), where people do not own cars and instead choose from a variety of transportation options to meet their needs for specific trips. As Table 2 indicates, the urbanites of Narrative 1 will likely benefit immensely from mobility-as-a-service. In dense urban areas, car-sharing and ride-sharing services complement public transit and active travel to offer remarkable freedom and flexibility. In urban areas, autonomous vehicles could further improve mobility options if they reduce the cost of providing public transit and ride-sharing.

By contrast, mobility-as-a-service is less likely to benefit Narrative 2 because those services will be less viable in low-density locations where there is a limited supply of and demand for peripatetic options. One possible exception is ride-sharing services, which may benefit Narrative 2 by supplementing insufficient suburban transit services. However, recent attempts at suburban commuter ride-sharing services, such as Bridj, have struggled, suggesting that microtransit can only survive with the help of government

\footnotetext{
${ }^{2}$ Although some of these changes are having immediate implications on millennials, clearly many of these changes will be felt by the next generation of young adults (currently unnamed). However, we assume for the sake of argument that the "two narratives" will evident in the next generation of young adults as well.
} 
subsidies (Bliss, 2017).

Rather than mobility-as-a-service, new transportation technologies may instead be incorporated into an ownership model. If so, Narrative 1 will likely still benefit more than Narrative 2 because the latter will be less able to afford automated vehicles until they reach the affordable used car market.

Table 2: Differential benefits of transport developments on two narratives

\begin{tabular}{|l|l|l|}
\hline Emerging technology & Narrative 1 & Narrative 2 \\
\hline Mobility-as-a-service & Supports multimodal travel in cities & Unlikely to benefit \\
\hline Car-sharing (e.g. ZipCar) & Supports multimodal travel in cities & Unlikely to benefit \\
\hline Ride-sharing (e.g. Uber, Lyft) & Supports multimodal travel in cities & $\begin{array}{l}\text { Possible benefits in suburban areas, may } \\
\text { replace infrequent transit if affordable }\end{array}$ \\
\hline Automatized vehicles (ride-sharing) & Supports multimodal travel in cities & $\begin{array}{l}\text { Clear benefits in suburban areas, may } \\
\text { replace infrequent transit }\end{array}$ \\
\hline Automated vehicles (individual ownership) & Likely to be early adopters & Unlikely to afford the technology \\
\hline
\end{tabular}

\subsection{Electric vehicles}

Like mobility-as-a-service, subsidies to encourage the purchase of electric vehicles will likely benefit Narrative 1 and do little to benefit Narrative 2. Early adopters of EVs (who tend to be more affluent) will benefit from relatively larger subsidies than later adopters (who tend to be less affluent). Just as Narrative 2 is able to afford EVs, subsidies for them will likely sunset. To make matters worse, as fuel tax revenues decline due to increasing vehicle efficiency and electrification, many governments will turn to the gas tax to increase revenues. This will disproportionately affect Narrative 2-who will still own traditional, fuel powered cars—while hardly affecting Narrative 1 - who will either own electric vehicles or who consume mobility-as-a-service.

\subsection{Road pricing}

Road pricing (via tolls, area-based-congestion pricing, or charging for parking) can help ease congestion and manage vehicle travel. Narrative 1 will not only benefit more from these polices than Narrative 2 (from more street space for bus lanes and outdoor seating), they will also shoulder less of the cost of any price increases for parking or tolls because they already own fewer cars and have more alternative modes available.

Narrative 2, by contrast, will suffer more from policies intended to curtail the car. Specifically, those who find automobile access out of reach due to financial constraints will find car ownership even further out of reach. Moreover, those able to afford automobile ownership today may find that they are no longer able to do so if prices increase (as indeed that is the aim of the policies).

\section{$5 \quad$ A future for both millennials?}

As mobility services, electric vehicles, and road pricing each become more prevalent, planners and policymakers should recognize that a "one size fits all" perspective on millennials is potentially misleading. In urbanized settings with strong transit services, supporting Narrative 1 should still be encouraged. Technological advances and sustainable transport policies in urban areas are likely to benefit many, not just affluent urbanites.

However, Narrative 2 should not be overlooked, particularly in regions where a lack of car-based transport is a significant barrier to employment and social participation. Relative to Narrative 1, meeting 
the needs of Narrative 2 may require more government intervention in the form of regulations, incentives, or direct service provision. For example, regulators may require or encourage ride-sharing firms to serve unprofitable (e.g., low-density and low-income) areas. Similarly, when developing road pricing schemes, policymakers may consider compensatory programs to ease the burden on those with few alternatives to the automobile.

Finally, transport policies alone cannot reduce social inequalities for low-income, low-educated millennials; efforts must be combined with affordable housing, education, and welfare policies. 


\section{References}

Bliss, L. (2017). Bridj is dead, but microtransit isn't. [Web log post]. The Atlantic's CityLab. Retrieved from https://www.citylab.com/transportation/2017/05/bridj-is-dead-but-microtransit-isnt/525156/

Blumenberg, E., \& Manville, M. (2004). Beyond the spatial mismatch: Welfare recipients and transportation policy. Journal of Planning Literature, 19, 182-205.

Brown, A. E., Blumenberg, E., Taylor, B. D., Ralph, K., \& Turley Voulgaris, C. (2016). A taste for transit? Analyzing public transit use trends among youth. Journal of Public Transportation, 19, 4.

Campbell, M. (2012, April 2). Young people choose computers over cars. The Age. http://www.theage. com.au/

Davis, B., Dutzik, T., \& Baxandall, P. (2012). Transportation and the new generation: Why young people are driving less and what it means for transportation policy. Santa Barbara, CA: Frontier Group.

Delbosc, A. (2016). Delay or forgo? A closer look at youth driver licensing trends in the United States and Australia. Transportation, 1-8.

Delbosc, A., \& Currie, G. (2013). Causes of youth licensing decline: A synthesis of evidence. Transport Reviews, 33, 271-290.

Delbosc, A., \& Currie, G. (2014a). Changing demographics and young adult driver license decline in Melbourne, Australia (1994-2009). Transportation, 41, 529-542.

Delbosc, A., \& Currie, G. (2014b). Impact of attitudes and life stage on decline in rates of driver's license acquisition by young people in Melbourne, Australia. Transportation Research Record, 2452, 62-70.

Grimsrud, M., \& El-Geneidy, A. (2014). Transit to eternal youth: Lifecycle and generational trends in Greater Montreal public transport mode share. Transportation, 41, 1-19.

Hjorthol, R. (2016). Decreasing popularity of the car? Changes in driving licence and access to a car among young adults over a 25-year period in Norway. Journal of Transport Geography, 51, 140-146.

Klein, N. J., \& Smart, M. J. (2017). Millennials and car ownership: Less money, fewer cars. Transport Policy, 53, 20-29.

Kuhnimhof, T., Buehler, R., \& Dargay, J. (2011). A new generation: Travel trends for young Germans and Britons. Transportation Research Record, 2230, 58-67.

Kuhnimhof, T., Buehler, R., Wirtz, M., \& Kalinowska, D. (2012). Travel trends among young adults in Germany: Increasing multimodality and declining car use for men. Journal of Transport Geography, 24, 443-450.

Le Vine, S., \& Polak, J. (2014). Factors associated with young adults delaying and forgoing driving licenses: Results from Britain. Traffic Injury Prevention, 15, 794-800.

Mcdonald, N. C. ( 2015). Are millennials really the "go-nowhere" generation? Journal of the American Planning Association, 81, 90-103.

Ministry of Infrastructure and the Environment. (2014). Not car-less, but car-later. The Hague: Netherlands Institute for Transport Policy Analysis.

Mulley, C. (2017). Mobility as a services (MaaS)—does it have critical mass? Transport Reviews, 37, $247-251$.

Oakil, A. T. M., Manting, D., \& Nijland, H. (2016). Determinants of car ownership among young households in the Netherlands: The role of urbanization and demographic and economic characteristics. Journal of Transport Geography, 51, 229-235.

Raimond, T., \& Milthorpe, F. (2010). Why are young people driving less? Trends in license-holding and travel behavior. Paper presented at the Australasian Transport Research Forum. Canberra, Australia.

Ralph, K., \& Delbosc, A. (2017). I'm multimodal, aren't you? How egocentric anchoring biases experts' perceptions of travel patterns. Transportation Research Part A: Policy and Practice, 100, 283-293. 
Ralph, K. M. (2016). Multimodal millennials? The four traveler types of young people in the United States in 2009. Journal of Planning Education and Research, 37(2), 50-163.

Rive, G., Thomas, J., Jones, C., Frith, B., \& Chang, J. (2015). Public transport and the next generation. Wellington: NZ Transport Agency.

Sakaria, N., \& Stehfest, N. (2013). Millennials \& mobility: Understanding the millennial mindset and new opportunities for transit providers. Washington, DC: Transit Cooperative Research Program, Transportation Research Board.

Santos, A., Methipara, J., \& Reuscher, T. (2016). Exploring travel behavior of millennials in cell phone only households. Paper presented at the Transportation Research Board 95th Annual Meeting, Washington, DC.

Taylor, B. D., Ralph, K., \& Smart, M. (2015). What explains the gender gap in schlepping? Testing various explanations for gender differences in household-serving travel. Social Science Quarterly, 96, 1493-1510.

Thigpen, C., \& Handy, S. (2016). Driver's licensing delay: A retrospective study of the impact of attitudes, parental and social influences, and intergenerational differences. Paper presented at the Transportation Research Board Annual Meeting, Washington, DC.

Zipcar. (2013). Millennials and technology. LinkedIn Slideshare. Retrieved from https://www.slideshare.net/Zipcar_Inc/millennial-slide-share-final-16812323 